\title{
Global Border Making and Securitisation in the Early Modern World: An Introduction
}

DOI:

https://doi.org/10.5871/jba/009s4.001

\section{Document Version}

Final published version

Link to publication record in Manchester Research Explorer

\section{Citation for published version (APA):}

Smith, E., \& Hellman, L. (2021). Global Border Making and Securitisation in the Early Modern World: An Introduction. Journal of the British Academy, 9(4), 1-12. https://doi.org/10.5871/jba/009s4.001

\section{Published in:}

Journal of the British Academy

\section{Citing this paper}

Please note that where the full-text provided on Manchester Research Explorer is the Author Accepted Manuscript or Proof version this may differ from the final Published version. If citing, it is advised that you check and use the publisher's definitive version.

\section{General rights}

Copyright and moral rights for the publications made accessible in the Research Explorer are retained by the authors and/or other copyright owners and it is a condition of accessing publications that users recognise and abide by the legal requirements associated with these rights.

\section{Takedown policy}

If you believe that this document breaches copyright please refer to the University of Manchester's Takedown Procedures [http://man.ac.uk/04Y6Bo] or contact uml.scholarlycommunications@manchester.ac.uk providing relevant details, so we can investigate your claim.

\section{OPEN ACCESS}




\title{
Global border making and securitisation in the early modern world: introduction
}

\author{
Lisa Hellman and Edmond Smith
}

\begin{abstract}
In the early modern period, borders could be mutable, imprecise, and represent far more than the lines on a map or delineation between sovereign states. In this essay, as well as introducing the eight articles that form the body of the special edition, we set out the key ideas that serve as a common theme and thread across this collected body of work. First, the idea of 'securitisation' is examined, and consideration given to how it has been used by both scholars in International Relations and more recently in historical studies. Second, we consider the concept of 'border making' and explore how re-examining our preconceptions about the idea of borders can change the way we examine important questions related to state and imperial formation, identity, and the meaning of community. Finally, the possibilities for using borders and security as entry points into asking new questions about 'emotional global history' are discussed, and how this could be useful for thinking more carefully about the tensions, frictions and entanglements, as much as connection and exchange, that are at the core of globalising processes that have done so much to shape the world as we know it today.
\end{abstract}

Keywords: Global history, borders, securitisation, migration, empire

Note on the authors: Dr Lisa Hellman (PhD, Stockholm 2015) is leader for the research group 'Coerced Circulation of Knowledge' at University of Bonn, and a Pro Futura fellow at the Swedish Collegium for Advanced Study. She works in the intersection between social, cultural, maritime and global history in East and Central Asia. Her publications include 'Enslaved in Dzungaria: What an EighteenthCentury Crocheting Instructor Can Teach Us About Overland Globalisation', Journal of Global History (2021), and their monograph This House Is Not a Home: European Everyday Life in Canton and Macao 1730-1830 (Brill, 2018).

Dr Edmond Smith (PhD, Cambridge 2016) is Presidential Fellow in Economic Cultures at the University of Manchester. Their work focuses on commercial communities and the institutions of early modern global trade. They have published numerous chapters and articles, including in the Economic History Review, Journal of Imperial and Commonwealth History, Historical Journal and Journal of Social History, and their monograph Merchants: The Community That Shaped England's Trade and Empire, 1550-1650 with Yale University Press (2021).

(C) The author(s) 2021. This is an open access article licensed under a

Creative Commons Attribution-NonCommercial-NoDerivs 4.0 Unported License 
Borders are more than lines on a map, they can be defined by laws, by customs, by language and by emotions, and they can be as hard to pin down as they are prone to change. In recent times, we have witnessed plenty of instances that have shown how borders are not inviolable or fixed: whether in the actions of Brexiters in the United Kingdom to resurrect and strengthen barriers within Europe; efforts of the African Union to break down long-imposed barriers to better battle climate change; or the imposition of COVID-19-induced controls that banned entry overnight between regions that had seen free movement for decades. In each case, shifting priorities and conceptions of what borders are for and how they can be used to serve one community or another, have resulted in changes to the way borders function, even if the lines on maps that represent them have remained unmoved.

In the early modern period, borders were similarly mutable, and as well as coming to define sovereign territories or delineate space on maps or surveys, they were also used as a means by which communities could secure themselves from perceived threats. During periods of uncertainty, such as during this period of increasing globalisation and imperial expansion, borders could be activated, and put into use, by people who sought to control or mitigate against the increased mobility and intercultural interaction that such processes brought about. In this special issue, each article sets out to understand how such border making practices came about as a response to these historical shifts, and to reflect on how individuals living within newly bordered communities, or crossing over borders, understood these changes and the impact of borders on their lives.

This special issue is focused on the period between 1500 and 1850, and presents eight articles that each engage with the idea of 'securitisation' to ask new questions about how borders were constructed and managed in the early modern world. During this time, the connections tying the world together changed: broadly speaking, the contacts became increasingly influential, common, direct and personal. This process of globalisation was by no means a smooth coming together, however. Rather the opposite, the entanglements of the premodern world disrupted existing trade routes, brought about vast colonial settlement and migration, and brought in its wake military, economic as well as epidemiological threats. ${ }^{1}$ As well as increased connectivity globally, this period also witnessed the spread of mapping and surveying as a means of constructing national and imperial borders across the world; in this special issue, we see those developments not as contradictory, but as resulting from one another. ${ }^{2}$ Across these articles, each author brings attention to the fact that this period of globalisation was not one in which borders ceased to exist, but in contrast was a period in which borders gained new importance and became connected to other scientific 
and political practices. Together, these eight studies, with wide geographical and chronological spread, represent an effort to contribute to the discussion of what borders have been, became, and why, and thereby further our understanding not only of borders, but also how they can shed light on broader histories of trade, empire and globalisation.

In global history, the questioning of the nation state as a primary analytical framework is an important theoretical foundation, as are spatial analyses and, as a field, it seeks to move beyond an understanding of historical process that are defined by such borders and instead seeks to trace developments that cross them. ${ }^{3}$ Despite, or perhaps because of this aim, the making of borders remains under-theorised within global history scholarship, and to some degree also empirically understudied. ${ }^{4}$ In response to this challenge, this special issue will thus draw on interdisciplinary scholarship related to both border making and political theory-especially the concept of 'securitisation'. In doing so, each article combines insights on border making from the field of geography with theories of perceived security and insecurity, and the resulting control of borders from the field of international relations, and makes use of the intersections between these fields to explore early modern practices of border making. These studies will take us on a journey across the globe, from the Baltic states to colonial Brazil, to the Sultanates of Sumatra and the Qing empire, and back to Europe and the Italian city states.

The articles in this special issue demonstrate the fruitfulness of considering border making as a response to uncertainties and a changing world. The authors' findings also, however, illustrate that neither the perceived uncertainties nor the response to them can be easily disentangled. While the cross-border mobility of some types of actors, commodities or knowledge were quickly restricted, others were not, nor did all political shifts follow the same pattern of threat and restriction. Rather than a natural response to any and all external pressure, the closing, changing or creation of borders was one of many potential strategies employed, and each were defined by the specific contexts in which they took place. What these studies do suggest is that attention to border making in global history might not so much require an update of the political history of empire as much as it necessitates the integration of the last decade's developments of the history of emotions. What sparks a shift in border policy is not so much a particular event, as the emotional reaction to it. ${ }^{5}$ By shifting our perception towards an understanding that borders can be constructed emotionally, culturally and communally, as much as by states or empires, we can begin to ask new questions about how they function and how they shape our globalising world.

\footnotetext{
${ }^{3}$ Middell \& Naumann (2010).

${ }^{4}$ Wang (2017); van der Vleuten \& Feys (2016).

${ }^{5}$ This goes back to works such as Robin (2006).
} 


\section{On securitisation}

By recognising how border making was a broad social and political process, we can more effectively use analyses of it to reconsider periods and interactions when the enforcement of existing border policies, or their adaption to meet changing circumstances, was deemed of paramount importance. In this collection, each article focuses on moments of increased interregional encounter, whether in the form of cross-cultural diplomacy, trade, colonisation, international work migration or captivity. Resulting borders that occurred as a consequence of these events can thus also be considered as a response to the concomitant uncertainty of a changing world, which makes efforts to create certain borders a process of 'security thinking' on the part of individuals and communities as much as by states.

To explain this process, the authors across this collection have applied the theory of 'securitisation' to their analysis of these moments of early modern encounter and what they reveal about border making. Securitisation is a theory that was developed within the field of International Relations that seeks to explain how the construction and labelling of 'threats' on a social and emotional level can be used to generate support for stronger 'security' measures, such as border making. It thereby shows how security concerns within a state or polity are not a natural given, but something carefully designated by so-called 'securitising actors' who have the social or institutional influence to engage wider communities in responding to perceived threats. That makes issues of security not a matter of fact, necessarily, but an effect of the persuasive articulation of a 'threat' by a certain actor. Indeed, a central aspect of securitisation theory is how political actors employ rhetorical structures when framing 'security' issues, and shows how words do not merely describe reality, but can constitute reality, triggering political responses. ${ }^{6}$ Contemporary and commonly studied examples include the securitisation - that is, the presentation of something as a threat - of immigrants, globalisation or religious difference, as a means of obtaining public support for 'securitising' policies. Dorothée Goetze's article in this issue exemplifies the use of similar discourse in an early modern context, showing how Lithuanian nobles in the Swedish Baltic empire attempted to rhetorically frame and reframe their understanding of perceived threats to the order of the empire in order to obtain political favour - a strategy that was, in that case, ultimately unsuccessful. ${ }^{7}$ For the study of early modern borders, then, this approach provides a useful tool for examining how the unwieldy process of border making could be both a top-down development imposed by states, empires, or corporations, but also a personal, even emotional affair, which was influenced by the communities affected.

${ }^{6}$ This goes back to Buzan (1983); Buzan et al. (1998); see also Buzan \& Hansen (2009).

${ }^{7}$ Goetze (2021). 
This approach, of connecting ideas related to securitisation with the analysis of historical border making, was the focus of an international conference held at the University of Bonn's Centre for Dependency and Slavery Studies in February 2020, where the articles here were first presented, discussed and developed. Building on these deliberations, the articles in this special issue challenge traditional interpretations of border making by carefully reconstructing how a range of different actors participated in border making, how they felt about and understood these changes, and how borders could be shaped by communal and social forces as much as political power. In doing so, we are indebted to the work of international relations scholar Christoph Daase, who presented a discussion of several historical analyses, particularly of the medieval period, in which the concept of securitisation was applied to a period long before the modern state existed. His conclusion was that the concept is useful for historical analysis in multiple ways - but that it has yet to find very much traction. ${ }^{8}$ Sari Nauman's article opens up this special issue with a detailed analysis of the concept of securitisation and its potential historical use, also exploring the possible problem that arise when applying a theory from International Relations - a field which already in its very name clearly assumes the existence of modern nation states - on a world in which such centralised states did not yet exist. ${ }^{9}$ As Nauman shows, the application of this theory can indeed help historians to explain the complex creation of threat and border within and between empires and polities, but it also requires a careful consideration of what constitutes a state.

What is more, the theory of securitisation helps us ask questions about power relations inherent in the making of borders, and the perceptions of threat. Some actors administer security, others receive security, and yet others are created as targets of securitisation - that is to say, they are presented as a danger. Thereby, security concerns produce uneven power relations. ${ }^{10}$ Such hierarchies could be racialised, but as shown in the article by Rolla, they could equally well be defined by class. ${ }^{11}$ The power relations similarly affected the referent object, that is, the thing that is presented as being threatened and as in need of protection. In these examples, that referent object could be a colonial regime, such as in the case of Veevers's article on the British colonial enterprise on Sumatra, but also a societal system, as the Lithuanian nobles in Goetze's article argued, or even the stability of the Chinese empire, shown to be the referent object in Barend Noordam's article. ${ }^{12}$ In each article in this collection, securitisation provides a focus that encourages the re-evaluation of border making

\footnotetext{
${ }^{8}$ Daase (2012).

${ }^{9}$ Nauman (2021).

${ }^{10}$ For this critical approach, see Williams (2003); Floyd (2011).

${ }^{11}$ Rolla (2021).

${ }^{12}$ Veevers (2021); Goetze (2021); Noordam (2021).
} 
that integrates communal and social perspectives with political determinations and state-defined borders.

In this respect, engagement with securitisation also presents a useful opportunity for each author to intersect with recent work on the history of emotion. In the past two decades, this field has shown how emotions not just influence politics, but constitute them. ${ }^{13}$ While many studies, especially those that link fear and political state policies, concern themselves with the modern period (the Cold War and the post-Soviet era feature prominently), there are also studies showing the potential of a much longer time perspective. In his study of 13th-century Livonia, for example, the historian Wojtek Jezierski uses the concept of emotional landscapes and 'empathy walls' to describe the making of the polity of Livonia, and the relationship between settlers, crusaders, missionaries and the native population. ${ }^{14}$ Emotions have also been linked to the making of the British empire during the early modern period, and used to explain ideas of home, threat, and economic and cultural dominance. ${ }^{15}$ By considering the emotional politics of border making, the authors here are contributing to the intersection between history and political theory - one that is based on the experience of creating borders, and perceiving a need for them. This need is not a simple top-down affair based on a 'rational' evaluation of future needs. Instead, the key to understanding the social side of borderlands history, we argue, is to take seriously the feelings of concern that drive practices of border making, and how those feelings were affected by processes of globalisation in the early modern world.

\section{On border making}

Rather than presuppositions for a polity to exist or as natural effects of the closer commercial ties between regions in the early modern period, borders here act as the objects of study. As recent research has shown, global histories of the early modern period have much to gain from seriously considering border making as a process: such a view highlights not only what was perceived as a pressure — or even a threat — by communities and states, but also the resources called upon to counter this. ${ }^{16}$ Focusing our attention to this process has the potential to break up any monolithic view of the state, and highlight the multiplicity of actors presenting parallel or competing claims to what a border should be and how it should function. Indeed, as Tamar Herzog argues: 'rather than being determined by treaties or military confrontations' borders

\footnotetext{
${ }^{13}$ See Laffan \& Weiss (2012).

${ }^{14}$ Jezierski (2020).

${ }^{15}$ Lydon (2019).

${ }^{16}$ Historical discussions of this theory include Adelman \& Aron (1999); Ludden (2011).
} 
represent 'the end result of multiple activities by a plethora of agents' whose actions 'defined the territories of their communities and state'. ${ }^{17}$ We can observe that process, especially, during moments of rapidly increasing global interaction-whether through trade, migration or conquest. In the modern era, the experience of globalisation 'actually created a demand for the use of modern tools of spatial abstraction' as a means for delineating borders. ${ }^{18}$ That process developed gradually, and in step with the process of globalisation itself: scientific mapping and world making is increasingly tied to the very idea of empire, in the way that it was conceptualised during the early modern period. While both this process of empire and the intertwined development of scientific mapping has been much studied for Europe, it was certainly not unique to it. ${ }^{19}$

For a long time, border studies within history, geography or international relations have focused on the making of 'hard' borders, that is political territorial boundaries, and their delineation in maps and in law. As the field has evolved, more and more attention has been paid also to 'soft' borders: fluid, porous, lived and imagined contact zones and delineations. In recent years, the division between hard and soft borders has been questioned, and they are now commonly stressed as parallel aspects of the processes of border making - indeed, that is the view applied in this special issue. $^{20}$ This combined approach allows for a complex view of borders, the actors who created them, as well as and the communities affected by them. Contemporary researchers now ask questions such as who acts as a 'carrier of a political border' in their everyday life, maybe even involuntarily, but stress that such everyday bordering does not represent a weak, or 'soft' border, and highlight that such a process can generate borders as absolute and functional as that of state-imposed regimes. ${ }^{21}$ This broadening of the understanding of borders actually goes hand in hand with the logic behind the development of the theory of securitisation. By end of the Cold War, some scholars in International Relations were dissatisfied with a narrow focus on the political stability of states. Feminist scholars, especially, played a key role in challenging the idea that the state was the sole provider of security; on the contrary, the state was often the cause of insecurities for women, and these scholars demonstrated how gender, war, foreign policy and issues of security were intertwined..$^{22}$ This nuanced understanding of power relations relative to different groups' experiences of the same

\footnotetext{
${ }^{17}$ Herzog (2015).

${ }^{18}$ Branch (2014: 105); see also Massey (2005).

${ }^{19}$ For a broad overview, see Heffernan (2014); for a non-European example, see Yee (1994); or Aksan \& Goffman (2007).

${ }^{20}$ The combining of these two seemingly contradictory visions has led to novel re-interpretations of often sidelined regions in global history. See, for example, Shao (2011).

${ }^{21}$ Brambilla (2015).

${ }^{22}$ See for example Muehlenbeck (2017).
} 
processes, also facilitates the analyses of historical examples: religious, political and economic borders were created simultaneously in the early modern period, but - as the authors of this volume demonstrate - they had different porosity and meaning for different actors.

As this special issue serves to illustrate, borders represent complex ecosystems, acting both as barriers and crossings, points of contact and conflict, and places of exchange and enforcement. As such, borders would be porous and solid simultaneously, and act as spheres of forced and voluntary integration parallel with processes of conscious exclusion. ${ }^{23}$ Who or what could pass these boundaries, and what was perceived as the relevant border at any given moment, reveals much about the organisation of specific communities and the hierarchies within them. For example, in her study of 18th-century Turin included in this issue, Nicoletta Rolla shows how any group that could be considered 'vagrant' was perceived as a unwanted, and were often presented as threatening the stability of the city. ${ }^{24}$ In contrast, Laura Di Fiore's article details how migrant workers and artisans in southern Italy in the 19th century could be seen as a sought-after and crucial workforce even while their movements were considered suspect..$^{25}$ It was thus not cross-regional migration per se that was targeted, but borders were set up to reach particular groups, with a particular kind of mobility. In global, colonial contexts, too, we see similar patterns and challenges in border making. Veevers, for instance, shows how the English East India Company sought to employ strictly delineated ideas of border making in 17th- and 18th-century Sumatra, but struggled to implement these in the face of the island's highly mobile workforce and complex political landscape. ${ }^{26}$ In Mariana Boscariol's article, in contrast, we see how Portuguese efforts to penetrate into trading networks in West Africa and China were stymied by local efforts to impose and maintain strict border regimes. ${ }^{27}$ In each case, and across the articles in this collection, we see how early modern borders represented complex systems that had to be negotiated, adapted and enforced in light of changing local and international pressures.

\section{Borders and security: towards an emotional global history}

By applying the lens of securitisation to understand border making in the early modern world, in a number of different contexts, the articles in this special issue

\footnotetext{
${ }^{23}$ For more on these parallel processes, see Ahmed (2000).

${ }^{24}$ Rolla (2021).

${ }^{25}$ Di Fiore (2021).

${ }^{26}$ Veevers (2021).

${ }^{27}$ Boscariol (2021).
} 
also intersect with a number of themes common in debates on early modern global history.

A classic example is how borders affected migration, and how their recreation or application became an effect of flows of migration..$^{28}$ As we can see in Nauman's article, ${ }^{29}$ the experience of Baltic refugees in the 18th-century Swedish empire show how this group was at times perceived as a danger to the stability of the state, leading to new security measures. This can be compared to the study presented by Rolla, in which groups classified as vagrants in Turin were also singled out as disruptive, and their access to the city restricted. ${ }^{30}$ As the article by Joachim Östlund shows, however, attention to migration does not only shed light on those attempting to move or gain access, or efforts to restrict them, but also those subject to forced migration. ${ }^{31} \mathrm{He}$ provides a dramatic example in the North African captivity and ransom of Swedish sailors in the 18th-century Mediterranean, arguing that the payment of this ransom eventually became not only a community issue, but also a state concern: while the threat affected individuals, and private commercial ventures, to free this group eventually became a matter that concerned the state as a whole. Just as the theory of securitisation has developed to pay more and more attention to non-state actors also in the shifting of state policies, state and non-state actors work in parallel to interpret the outside world; to apply a strict analytical division between them might obscure more than it reveals.

Another way in which border making might help explain early modern global connections is the circulation of knowledge. In Noordam's article, we are presented with a view of how contacts between the Ottoman and the Qing empire developed between and through different official embassies, and he uses the example of military technology to see the limits of that exchange. ${ }^{32}$ However, Noordam also shows how the presentation of the foreign as a threat, even in relation to useful knowledge that might be obtained through such links, should be understood as part of national political concerns, as much as part of foreign policy. This helps raise the issue of how borders differed between types of flows, for example that certain types of knowledge could travel easier than others. ${ }^{33}$ A similar example related to this theme is that of Boscariol's case study in West Africa, in which trade is clearly both encouraged and delineated at the same time. ${ }^{34}$ This control shows clearly how the flow of goods could

\footnotetext{
${ }^{28}$ For an overview, see Manning \& Trimmer (2020).

${ }^{29}$ Nauman (2021).

${ }^{30}$ Rolla (2021).

${ }^{31}$ Östlund (2021); and see Eltis (2002).

${ }^{32}$ Noordam (2021).

${ }^{33}$ This point has been raised by Proctor (2008); Finn (2010).

${ }^{34}$ Boscariol (2021).
} 
be perceived as less threatening than the presence of those perceived as outsiders, and how early modern states balanced profit versus the seriousness of potential dangers, just as modern states do.

Across these articles, the authors clearly show how the making of borders and the globalisation of the early modern world were not contradictory, but in fact intertwined processes. Despite this fact, many insights from geographers and International Relations scholars about how border making functions, and how it intertwines economic, cultural, social and political concerns, are not really put to work in global history. While a classic approach to global history is to try to move beyond the nation as a framework, one way to do that might be to focus on the complex making of borders themselves. To use a simile: gender history has demonstrated that the questioning of the male norm might require attention to the construction of masculinity itself, not only to examples of femininity breaking that norm. Much in the same way, questioning the nation state and national borders might mean that we need to pay it more attention, not less. Doing so might allow us to connect to the field of global history's increasing focus on the losers of globalisation, its frictions and entanglements, and the disconnections that can be identified within this process. Thereby, global history might represent one of the fields that has the most to win by the focus on border and security that this special issue proposes, as it can help not only identify the existence of friction and disconnections, but explain why they arise, and consider them as response to an insecurity that is also emotional.

\section{Conclusion}

Taken together, the authors demonstrate how attention to the making of borders can illuminate many key issues not only of how the early modern world changed, but also of the reactions that change sparked. Connections led to exclusions based on class, profession, religion and ethnicity - and they did so by presenting certain groups as a menace, and sparking fear. Thereby, this issue shows the value of paying attention to diverse practices of border making, especially for global history. What is more, it highlights the analytical potential for historians to draw upon theories from International Relations when approaching global border making, and points to the necessity to also consider emotional concerns in that process.

Theories such as that of securitisation certainly stem from a particular historical context, and it is not uncomplicated to apply ideas based on a world of modern nation states and inspired by the end of the Cold War to a world where the nation states had not yet formed, and the political system looked different altogether. The key takeaway from combining such a theory with historical examples spanning the early modern world is to consider security concerns, regardless of 
the form they take, as a basis for the making of borders - which, in turn, paves the way to explore an emotional world making. People's worries, hopes and dreams might be explored as a reaction, and as something that in turn helped shape the global connections in the early modern era; this is a venue that deserves to be explored more in the future.

\section{References}

Adelman, J. \& Aron, S. (1999), 'From Borderlands to Borders: Empires, Nation-States, and the Peoples in Between in North American History', The American Historical Review, 104(3): 814-41.

Ahmed, S. (2000), Strange Encounters: Embodied Others in Post-Coloniality (London, Routledge).

Akerman, J.R. (ed.) (2009), The Imperial Map: Cartography and the Mastery of Empire (Chicago, University of Chicago Press).

Aksan, V.H. \& Goffman, D. (eds) (2007), The Early Modern Ottomans: Remapping the Empire (Cambridge and New York, Cambridge University Press).

Bayly, C.A. (2004), The Birth of the Modern World, 1780-1914: Global Connections and Comparisons (Oxford, Blackwell).

Belich, J., Darwin, J., Frenz, M. and Wickham, C. (eds) (2016), The Prospect of Global History (Oxford, Oxford University Press).

Boscariol, M. (2021), 'São Jorge da Mina and Macao: A Comparative Reappraisal of European Encounters', Journal of the British Academy, 9(s4): 32-57.

Brambilla, C. (2015), 'Exploring the Critical Potential of the Borderscapes Concept', Geopolitics, 20(1): $14-34$.

Branch, J. (2014), The Cartographic State: Maps, Territory, and the Origins of Sovereignty (Cambridge, Cambridge University Press).

Buzan, B. (1983), People, States and Fear: An Agenda for International Security Studies in the Post-Cold War Era, 2nd edn (London, Harvester Wheatsheaf).

Buzan, B. \& Hansen, L. (2009), 'Widening and Deepening Security', in B. Buzan \& L. Hansen (eds), The Evolution of International Security Studies (Cambridge, Cambridge University Press), 187-224.

Buzan, B., Wæver, O. \& de Wilde, J. (1998), Security: A New Framework for Analysis (London, Lynne Rienner).

Daase, C. (2012), 'Die Historisierung Der Sicherheit', Geschichte Und Gesellschaft, 38(3): 387-405.

Di Fiore, L. (2021), 'Security and Border Making in 19th-Century Southern Italy', Journal of the British Academy, 9(s4): 137-50.

Eltis, D. (ed.) (2002), Coerced and Free Migration: Global Perspectives, the Making of Modern Freedom (Stanford, Stanford University Press).

Finn, M. (2010), “Frictions” d'empire: les réseaux de circulation des successions et des patrimoines dans la Bombay coloniale des années 1780', trans. C. d'Albis, Annales: Histoire, Sciences Sociales, 65(5): 1175-204.

Floyd, R. (2011), 'Can Securitization Theory Be Used in Normative Analysis? Towards a Just Securitization Theory', Security Dialogue, 42: 427-39.

Goetze, D. (2021), 'Managing Legal Pluralism: The Negotiations on the Re-acquisition of Crown Land in the Livonian Diet (1681) as a Matter of Securitisation and Imperial Integration', Journal of the British Academy, 9(s4): 90-111.

Heffernan, M. (2014), 'Introduction: People, Places, and Ideas in the History of Cartography', Imago Mundi, 66(sup1): 2-4.

Herzog, T. (2015), Frontiers of Possession (Cambridge, MA, Harvard University Press). 
Jezierski, W. (2020), 'Politics of Emotions and Empathy Walls in Thirteenth-Century Livonia', in A. Mänd \& M. Tamm (eds), Making Livonia: Actors and Networks in the Medieval and Early Modern Baltic Sea Region (London, Routledge), 113-42.

Laffan, M. \& Weiss, M. (eds) (2012), Facing Fear: The History of an Emotion in Global Perspective (Princeton, Princeton University Press).

Ludden, D. (2011), 'The Process of Empire: Frontiers and Borderlands', in C. Bayly and P.F. Bang (eds), Tributary Empires in Global History (London, Palgrave Macmillan), 132-50.

Lydon, J. (2019), 'Introduction: Emotions and Empire', in J. Lydon (ed.), Imperial Emotions: The Politics of Empathy across the British Empire (Cambridge, Cambridge University Press), 1-24.

Manning, P. \& Trimmer, T. (2020), Migration in World History, 3rd edn (London, Routledge).

Massey, D. (2005), For Space (London, SAGE Publications).

Middell, M. \& Naumann, K. (2010), 'Global History and the Spatial Turn: From the Impact of Area Studies to the Study of Critical Junctures of Globalization', Journal of Global History, 5(1): 149-70.

Muehlenbeck, P.E. (ed.) (2017), Gender, Sexuality, and the Cold War: A Global Perspective (Nashville, Vanderbilt University Press).

Nauman, S. (2021), 'Securitisation of Space and Time', Journal of the British Academy, 9(s4): 13-31.

Noordam, B. (2021), 'Securing the Emperor, Securitising the Guns: The Strangely Delayed Dissemination of Ottoman Military Technology in the Late Ming Empire', Journal of the British Academy, 9(s4): $112-36$.

Östlund, J. (2021), 'Swedish Reciprocal Ransoms and Multinational Solutions to Insecurity in the Mediterranean, c. 1720-1740', Journal of the British Academy, 9(s4): 151-67.

Proctor, R.N. (2008), 'Agnotology: A Missing Term to Describe the Cultural Production of Ignorance (and Its Study)', in R.N. Proctor \& L. Schiebinger (eds), Agnotology: The Making and Unmaking of Ignorance (Stanford, Stanford University Press), 1-36.

Robin, C. (2006), Fear: The History of a Political Idea (Oxford, Oxford University Press).

Rolla, N. (2021), 'Communities Beyond Borders: Internal Boundaries and Circulations in the 18th Century', Journal of the British Academy, 9(s4): 168-89.

Shao, D. (2011), Remote Homeland, Recovered Borderland: Manchus, Manchoukuo, and Manchuria, 1907-1985 (Hawai'i, University of Hawai'i Press).

van der Vleuten, E. \& Feys, T. (2016), 'Borders and Frontiers in Global and Transnational History: Introduction', Journal of Modern European History, 14: 29-34.

Veevers, D. (2021), 'Building Borders in a Borderless Land: English Colonialism and the Alam Minangkabau of Sumatra, 1680-1730', Journal of the British Academy, 9(s4): 58-89.

Wang, J. (2017), 'Reckoning with the Spatial Turn: Cartography, Territoriality, and International History', Diplomatic History, 41(5): 1010-18.

Williams, M.C. (2003), 'Words, Images, Enemies: Securitization and International Politics', International Studies Quarterly, 47: 511-31.

Yee, C.D.K. (1994), 'Traditional Chinese Cartography and the Myth of Westernization', in J.B. Harley \& D. Woodward (eds), The History of Cartography, II:2 (Chicago, University of Chicago Press), 170-202.

To cite the article: Lisa Hellman and Edmond Smith (2021), 'Global border making and securitisation in the early modern world: introduction', Journal of the British Academy, 9(s4): 1-12.

DOI https://doi.org/10.5871/jba/009s4.001

Journal of the British Academy (ISSN 2052-7217) is published by

The British Academy, 10-11 Carlton House Terrace, London, SW1Y 5AH

www.thebritishacademy.ac.uk 